\title{
Uventira as a Symbol of Environmental Movement
}

\author{
An analysis on the contestation of ecological citizenship \\ Jamaludin Jamaludin*, Imran Imran, Sunarto Amus, Zumrotin Nisa \\ Universitas Tadulako \\ Palu, Indonesia \\ *jamaluntad@gmail.com
}

\begin{abstract}
This research aims at discovering and reviewing the information of the pattern of acts and public opinion on the values of Uventira local wisdom. This research employed qualitative approach using ethnography method. To Kaili has mythical beliefs of the invisible city Uventira which constructed as a zone of the supernatural creatures. The existence of uventira has an impact on human thought and action in maintaining the balance of nature. Uventira is a symbol of environmental movement because it is able to change and develop the human mindset and action in carrying out its sense of responsibility and love for nature. This kind of attitude promotes ecological and citizenship awareness.
\end{abstract}

Keywords—uventira; environmental movement;

\section{INTRODUCTION}

The recent environmental issues caused by the growth of population and the rapid development of science and technology [1]. Naturally, human beings are inseparable from their habits, tradition, and culture. Humans are learning to think, to feel, to believe, and to carry out all the things in accordance with their culture. Language, friendship, eating habit, communication practice, social acts, economic and political activities and technology advance based on the cultural patterns. The future of the world is determined by the culture and civilization developed by the current inhabitants of the world [2].

A culture be will developed through the rational way of thinking since the characteristic of culture is not static and always changes. It is indicated by the logical way of thinking to solve the problems. For example, in the past, most people will go to see dukun (indigenous medical practitioner) when they are sick, but now, they will prefer to see a doctor than to see dukun. The technological advance alters the pattern form of humans' lives, in which they are more pragmatic, hedonist, secular, effective and efficient on their behavior and attitudes, and the technology creates 'instant generation' [3].

A culture is a form or a shape of the behavior of people who occupy a region. The Ngata Toro indigenous peoples, located in Kulawi sub-district, who are in contact with the To Kaili community, known as a community with very strong social institutions and custom institutional systems have three equal high elements in their government structure, namely Totua Ngata, Maradika, and Tina Ngata [4]. Habits develop continuously from generation to generation and are believed by the people. Siregar proposed "culture is the whole way of life of a society and it is not merely about the higher and more desirable way of life." one of the cultural elements that are still be preserved by the Indonesian people toward cultural change is the belief system [5].

The belief system is a guide and a way of life for the people because of the ancestral heritage that must be preserved even in modern times. The origin of the belief is that people have a belief in a greater power than they have. This belief encourages people to believe in supernatural things. The tradition of worshiping sacred places is still carried out by some communities, the tradition cannot be separated from the myth. Therefore, humans do various things to achieve peace of life [6].

The belief system that has been entrenched in society indirectly and unintentionally will create a traditional wisdom of society to its surrounding. Such wisdom is usually called as a local wisdom. Local wisdom is a cultural product of the past which is constantly used as the grip of life. Although it has a local value, the content of the value is considered to have universal meaning.

The inherent feature of traditional wisdom that it has dynamic, sustainable, and acceptable characters. In local communities, traditional wisdom is interpreted as a set of rules, knowledge, skills, knowledge, values, and ethics that govern the social order of communities that always exist and evolve from generation to generation. In the concept of divinity, for example, it is often to hear the term Dewata Seuwa (in Bugis society) and Tau riA'rana (in Makassar society) and its existence is acknowledged. Farming and fishing communities still carry out traditions such as "mappangregalung" and "macceratasi" [7]. The existence of local wisdom encourage the member of thecommunity to obey its cultural order and it can create a sense of togetherness, commonality, and solidarity among each other [8].

The To Kaili community, scattered in some areas of Central Sulawesi, also has a belief in the unseen things of "Uventira" which is described as the area where the supernatural beings live, and the community calls it the residents of uventira. However, such belief in supernatural beings can only be understood by certain groups. The ritual is considered as a gratitude as well as a mediation for the salvation and luck of life.

Uventira is a form of inheritance that is still preserved as a belief system between humans and the ancestors. It is still 
maintained and undertaken by people in Tanantovea Subdistrict, the community in Tawailisub-district, and the Community in Parigi Utara sub-district, Central Sulawesi Province. They believe that the tradition of the ancestors always brings goodness to their descendants and should be regarded as a universal reason.

Public belief in the existence of Uventira area which is a cultural heritage passed down from generation to generation and regarded as the role and responsibility of the society to its environment, in creating various mindsets and actions of the community as a form of contestation of ecological citizenship toward the Uventira region. The values and practices they teach and do are still often considered ancient, but they are the best way to preserve the environment in post-modern times [9].

The collection of stories intertwined with the culture of the Uventira community voiced out the beliefs as social behavior and models of moral behavior. Utilizing natural resources and human resources by harmonizing the human activities with sustainable natural resource capabilities that can support the sustainability of the environment [10]. Thus, the pattern of environmental conservation is taught in the ethics of life by imitating the local wisdom of society [11].

The form of local wisdom emphasizing the values of local wisdom that are still carried out by the society from generation to generation and itbecomes a public belief in the Uventira region is interpreted as an environmental movement and contestation of ecological citizenship.

Adnyana states that the local wisdom of the Balinese Society has three values in their lives, they are the value of Tri Hita Karana is which is regarded to have an important role to maintain the relationship between humans with God, between human with others, and between humans with their environment. Thus, humans' perception and conception of a particular object have differences in terms of judging, assessing, and observing objects, and then drawing conclusions [12].

\section{METHOD}

The method used in this research is a qualitative descriptive method and ethnographic case study. The researcher employed this method by considering that the study of local wisdom collected that the data from informants. Qualitative research methods are conducted in a reasonable situation (natural setting) and the collected data are in the qualitative form. The location of this research wasTawaili sub-district, Tanantovea sub-district, and North Parigi sub-district which located around Uventira area.

\section{FINDING AND DISCUSSION}

Uventira is an area located in the province of Central Sulawesi. The area is located in the highlands of the mountains around the area of Parigi Moutong District and Palu City. Uventira is a name given by the people who inhabit Kebun Kopi area or Trans Sulawesi road of Palu Parigi. The meaning of the word Uventira has different meanings to different societies.
The public believes that Uventira is a city full of gold and the richest city in the world that it is a sinking atlantis city. The meaning of Uventiraderived from the words uve and tirawhich means our water which in Rai Kaili language it meansred water. Despite many meanings expressed by communities regarding the meaning of Uventira, it has the same purpose of forming a belief in supernatural beings that have power and great effect on human life. Thus, the public believes that each human being in the world should not only believe in the visible things but also believes in invisible things. Public belief in the meaning and the existence of Uventira area has been attached to the community reside inthe Uventira area and also to the wider community. The existence of public belief in things that unseen indirectly make reference. The public belief in supernatural beings, indirectly become a reference that if there is something that happens toa man, the cause may be driven by his own activity.

The existence of various rules and restrictions concerning the myth of the existence of uventira has been entrenched in the mindset and actions of society. Belief in the prohibition of bringing eggplant, honking three times and greet/Tabe when crossing the road of Uventira area, and getting out of the vehicle for a moment to burn a cigarette, put a drink on the monument of uventira as a form of respect or excuse to the supernatural beings. It can be concluded that when crossing the area of Uventira, people do respect for supernatural creatures that are believed to always be on the human side, and affirms the power of thought and public belief on supernatural beings of Uventira.

Many people believe that Uventira as a region supernatural city, and there are some facts that occur irrationally. Uventira area is considered a supernatural city/ region since some people who pass through the area often experience strange feelings, they often saw strange things such as a man dressed in white and heard strange sounds. It is something that can make people around the area Uventira and the public widely believe and pay attention to the existence of Uventira.

A culture that is hereditarily preserved will be the identity of a region. The area of Uventira with various beliefs and rituals performed by the community is believed by the local people and by the wider community to have an impact on human life. One of the rituals performed by the community is Sambulugana ritual. The people believe that in the palace Uventira sambulugana is a great custom and also food for those who live in Uventira. The sambulugana ritual is performed when the community will carry out an activity or will enter the invisible city of Uventira or pass through Uventira area and it is done every Friday night inkliwon cycle.

In sambulugana ritual should provide offerings such as cigarettes, flowers, and betel. People believe that those who live in the palaceis a betel eater, some of them are manggerante, pue lasadindi, pue bendera, lapolego but there are exceptions that are the queen mother hajjah nur intan who is assumed consume flowers. The meaning of cigarettes: Surya Cigarette (Cigarette for the deaf people) and cigarette Gudanggaram (cigarette for nenekbendera). In addition, people who participate in the ritual must wear yellow, white, and red cloths.The meanings of these three colors are (yellow, white, 
red) is yellow as a symbol of prosperity (gold), white as a symbol of purity, and red as a symbol of bravery.

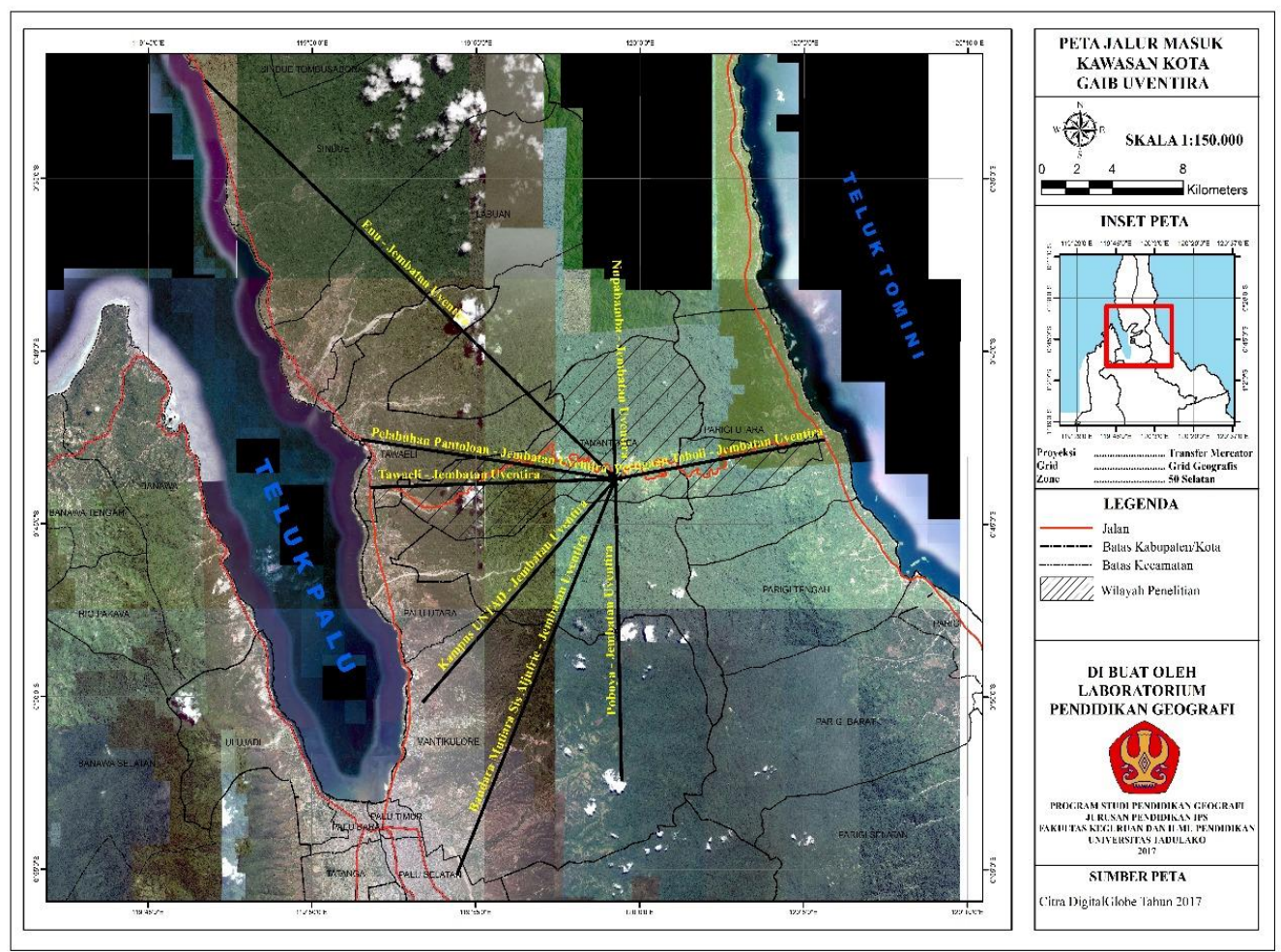

Fig. 1. Map of entrance road to invisible city Uventira.

Uventira region which lies in the mountainous area of coffee plantations is forest areas prone to landslides so that people do various ways to preserve the forest that can help prevent natural disasters. The commuinity's belief that the area of uventira is inhabited by spirits who are convicted to be able to do well, but they will do evil when humandestroy the environment. Hence, the directions or roads heading to the area of uventira are closely guarded by some ghost gods. the first door is guarded by the horse god, the second door is guarded by the leopard, the third door is guarded by the lion god, the fourth door is guarded by the cobra god, and the fifth door is guarded by the ghost of the kalomba, the sixth door is guarded by the hulubalang, and the seventh door is guarded by the ghost of a striped dog. The seven roads to the uventira area covers some spots such asSis-Aljufri airport, Nopabomba, Tawaili, STQ Mountains, Untad, Poboya, and Sindue. Internalization of local wisdom values is a way or an example to maintain the balance of nature and sustainability of uventira forest area.

Kontjarangingrat reveals that many tribes around the world believe that the spirit that has left one's body then the soul may inhabit on the place of the spirit, may live in the new body, and remain around the human residence [13].

The belief system of the Uventira is established among To Kaili people who believe thatthe area of uventira is inhabited by a soul that leaves the body, then becomes a supernatural being. Furthermore, they also believe that objects and plants have personality and willingness. Kontjaraningrat states that in the evolution of religion, humans believe that the spirits that can not be captured by human senses can do things that human beings can not do, they inhabit the natural surroundings of human dwellings [13]. These spirits have a very important place in human life, thus making them the objects of respect and worship, which are performed with various ceremonies, prayers, and offerings.

The myth of uventira is very functional in building the mindset and of the society, it can be noticed in the customs of the people to instil the value of the supernatural virtue of uventira from generation to generation so that people believe that this nature must be preserved and should not be destroyed.

The implementation of the value of local wisdom of uventiracan be seen with the existence of environmental concerns expressed with an attitude that supports the prohibition or taboos in conducting activities in the region. The manifestation of this attitude is the willingness to do things that can improve and maintain the quality of the environment. Therefore, if the community will conduct activities around the Uventira area, they must implement and comply with all existing rules such as performing rituals and obeying all restrictions.

Sambulugana is the key of all movements to get to the location or conduct activities in the Uventira area. Communities believe in the conditions and restrictions they must obey when entering the Uventira area. One thing that should be kept in mind that people can take whatever they need but they must only take the amount they need, with a condition that they must prepare sambulugana. The existence of these 
regulations may raise people's awareness of the natural preservation.

People's belief that uventira inhabited by supernatural beings has existed from ancient times until now and become a part of the culture of society who live in the area of Uventira. and the wider community. The area is convicted to affect life in the immediate surroundings of Uventira directly or indirectly, both to humans and to the conservation of the natural environment. Despite there are many different perceptions, they do not affect the meaning of Uventira itself nor the beliefs and traditions of the society that show the patterns of conduct, norms, values, and other aspects of life that characterize the Uventira community.

The belief that Uventira is a supernatural city affect greatly in the way of thinking of the community who live in around Uventira and the wider community on the sustainability of nature or forest area Uventira. They believe that there will be a catastrophe if they destroy the forest area of Uventira, because basically, humans have an awareness of their existence and position as a creature who live side by side with fellow creatures, and the whole of nature and its contents and supernatural beings or supernatural power that manage and control the relationships of humans with regard to other creatures.

Ecological citizenship is regarded as a relationship between humans and the environment. If humans or citizens do not preserve and protect their environment there will be regional damage. As a citizen, human beings can live side by side with nature and aware that nature is significant to the human life and for the sustainability of a society.

Everyone must have a high level of awareness of a cultural heritage existed on his environment. Such awareness can be indirectly transmitted to others, resulting in the collective action of a large number of people who support and embrace the culture in their lives. Similarly, the habits that are undertaken by people around the area Uventirahas greatly affected the one's habitwho passes on or conduct activities in the area. Therefore, the acceptance of the culture and maintain it from generation to generation impacts on the conservation of Uventira forest.

The community believes that the forest area is a place to live and a place where people perform various rituals such as sambulugana. Although these supernatural beings are not visible and only a few people can communicate directly with them but neighbouring communities and the wider community believe that there are supernatural powers so that those who will go to the Uventira forest area must obey the rules. This is as a result of a human understanding of all the occurrence events and becomes the basis of consideration in carried out an activity.

A local wisdom or a custom conducted by the community who live the Uventira region provides an example of how to preserve the culture and being wise and tactful in conserving the environment. In addition, it gives an example of the communities' love to their God, to the environment, to fellow human beings, as well as the relationships with other living beings (supernatural creature) who live side-by-side with humans. Thus, it can be said that the culture of Uventira society can influence wider community and establish a belief in the occult forces inhabiting the region and affect the community's activities in preventing the occurrence of a natural disaster and supporting the environmental conservation.

The history of the myths that developed in the Uventira region already existed from ancient times that have been entrusted and recognized by the wider community. The belief system embodied in the ritual implements and other customs that are entrenched and preserved until now. Cultural preservation is inseparable from the awareness of the generation to the inherent responsibilities of the values.

Based on the results of interviews, to elder people who are assumed to have a more in-depth knowledge of the myth of Uventira's existence, as well as to young people. In general, they revealed that the myths about Uventira are maintained well sincethe customary board believes that the resident of the palace of Uventira, the invisible city, do not want any crowd at their environment. A culture of positive value can develop and accepted by the wider community.

The outgrowing myth of Uventira is an example of a custom that should be maintained since it has a positive value. A culture is still being preservedover generations, not only by thecommunitywho live around the Uventira area but also by the wider community.Sambulugana ritual which is done every Friday night in kliwon cycle by inviting young people who believe in the myth of Uventira, to open their mind so they can see occult and they are able to communicate with supernatural beings and conserve the environment of the Uventira area. It provides insight and a sense of responsibility because they have been given life, for that reason they are obliged to conserve, maintain, and protect the environment. In general, public's beliefs about the invisible city of Uventira are interpreted as an environmental preservation since many people are afraid to undermine the nature/ environment that is convicted to be the location of Uventira. As we all know that environmental problems occur as a result of human activities. The utilization of natural resources will cause some changes to the ecosystem that will affect the sustainability of the natural resource. Therefore, community living in the area of Uventira are overprotectiveof the forest, since they believe that spirits inhabit the area. Therefore, the Uventira people are guarding the forest which is believed to be the city of Uventira where the supernatural beings are, and if the forest is damaged it will provoke anger by the supernatural beings that will create catastrophe or danger.

For example, Uventira area once planned as a tourist object, but when the plan will be implemented, something occurred and blocked the site. It is believed that the incident indicated that Uventira inhabitants did not allow the area to be a tourist spot. It needs to maintain and preserve the traditional way of life of the communities living in the area of Uventira. This way of life impacts on the preservation of nature, community living around Uventira has a tradition that must be carried out by people. The tradition is manifested in the form of a traditional ceremony as a procession to enter the invisible city of Uventira or called as sambulugana ritual. 
The procession of entering the invisible city of Uventira is done in several ways. The first procession is to turn on 3 incense, then prepare a table covered with yellow cloth which covered the table then put 5 baskets (dual') covered with yellow cloth, for the first three dula' use red, yellow and white cloths, each of which has a length of about 1 meter and the fabric is folded to triangular shape. On the top of these 3 dula'is placed 1 handful of jasmine flowers, 1 handful of canangaflowers, 1 bud of rose. Then another dula', is used as a container to place offerings such as 7 betel leaves, 7 betel leaves, 7 betel leaves, 7 gambier pieces, 7 tobacco and 1 betel powder, and the other dula 'contains 1 pack of cigarette Gudang Garam Merah, 1 pack of cigarette Surya, 2 boxes of wooden matches, a sum of money Rp. 177.700 and Rp. 77.00 as dowries. As preparation to get to the location of Uventira, everyone is obliged to wear yellow clothing, have a good intentions, should not be scared, do not reprimand what they see in any form, should not be overwhelmed because they are believed to be the meaning of our challenge for them, then greeted for 7 times, recited AlFatihah for 7 times, and recited Al-Ikhlas for 7 times ".

Some procession as parts of the ritualsto get to Uventira are, climb up the mountain up to $100 \mathrm{~m}$, then put 7 incense in front of the twin gates that are believed to be the place of treasure, and say excuse before getting inside. Afterwards, continue to climb up the mountain to see door 4 which is located about 400 meters from the main road, around the door 4 there are 1 traditional house and 4 places of worship (meditation), and put 7 burnt incense. Then continue the journey to door 5 . As information, the distance between door 4 and door 5 is about 50 meters, and the distance to get to door 6 about $350 \mathrm{~m}$. The total distance to reach door 7 is about $500 \mathrm{~m}$.

As the initial procession of this ritual, everyone is obliged to perform ablution, then both men and women are given yellow cloth to be worn on the head. For men, the cloth is worn as the head wrap while for women, the cloth is used as head cover. There are some people, who do not wear the cloth on their heads but also wear the cloth as a sarong. After that, everyone sat in the reserved area. At 12:17 a.m., the ritual began led by 1 speaker/shaman accompanied by 2 assistants. During the ritual, they still greeted for 7 times and they were asked to do dzikir.

About 15 minutes after the ritual began, the ritual successfully invited the inhabitants of Uventina's palace, as a response to the dukun's invitation. Then some people are asked to convey the purpose of their arrival.

As the fulfilment of the call from the dukun then called some people for the delivery of the intention of their visit to Uventira. Various ways are done by certain communities to preserve the culture that their ancestor had done. Communities around the Uventira region preserve the culture of their ancestors in the form of rituals and conservation of forests. The communities believe that the Uventira palace also has a customary team that does not want any crowds to occur in Uventira. Therefore, the community conservesand protect the forest from irresponsible people who want to destroy the forest. The contents of Uventira's palace is equal to $1000 \mathrm{x}$ of the world's contents and for those who damage the environment will get misfortune. Some restrictions that must be considered by the people who want to get to Uventira site. Those are, the prohibition of taking photos or taking video without permission, have a bad intention and exaggerated surprised. Such prohibitions are aimed at preserving the culture and conserving the environment around the Uventira area.

As we have understood that Uventira region contains myths and messages from ancestors containing prohibitions, taboos, and rituals in conducting activities around the area. The existence of local wisdom in the form of prohibitions, taboos, and rituals is understood to avoid crowds at that location and to conserve the ecosystem of the Uventira region especially ecosystem along the roads to the invisible city of Uventira and the mountains of Kebun Kopi which is believed to be the invisible city of Uventira. Thus, the value of local wisdom in the community around the area Uventira can affect the thinking way of the community of the sense of responsibility. It is expected to be good citizens, they can live in harmony with nature, develop a sense of mutual help in preserving the environment, and respect the noble values prevailing in the society. These values are used to protect and manage the environment sustainably.

\section{CONCLUSION AND SUGGESTION}

Based on the result, it can be concluded that Uventira is an area located in the mountainous area of kebunkopi, and is a way to get to the invisible city of Uventira. There are 7 doors connected to various places. Uventira is believed to be the richest invisible city in the world that it is a sinking Atlantis city and inhabited by supernatural beings. Sounding the horn and saying the word "Tabe" when passing the roads in the Uventira area, provide offerings, and do not take forest products excessively. All these things are habits that are done by people who live in the area around Uventira region which is interpreted as a respect forthe supernatural beings, effort to preserve the culture, and conserve the ecosystem and forest sustainability in the area. People believe that the invisible city of Uventirais guarded and protected by supernatural beings who do want any crowds occurs in their area.Uventira region contains myths and messages from ancestors containing prohibitions, taboos, and rituals in conducting activities around the area. One of the tradition is sambuluganaritual is performed when the community will carry out an activity or will enter the invisible city of Uventira or pass through Uventira area and it is done every Friday night inkliwon cycle.Despite there are many different perceptions, they do not affect the meaning of Uventira itself nor the beliefs and traditions of the society that show the patterns of conduct, norms, values, and other aspects of life that characterize the Uventira community.

The existence of local wisdom values in the area Uventira formed a pattern of community behavior and give a positive impact on the sense of responsibility towards fellow beingswho inhabit space and raise people's awarenessto preserve the culture and conserve the environment. The history of the myths developed in the Uventira region already existed from ancient times that have been entrenched and recognized by the wider community. The belief system embodied in the rituals and other customs become a culture which is maintainedand preserved to this day. 
Given the importance of local communities' role in preserving their environment, it is important to maintain and protect the people'sactivities as a form of ecological wisdom.Local wisdom in the Uventira region needs to be preserved and it needs awareness of the young generation to always maintain the culture. It needs to establish a more strict prohibition and formulate the prohibition in the written formthatis accepted by the wider community in relation to the forest utilization and activities in Uventira area. A further research is required to organize forest conservation management system in Uventira area.

\section{REFERENCES}

[1] Sumarmi, and Amirudin, Pengelolaan Lingkungan Berbasis Kearifan Lokal, Malang: Aditya Media Publishing, 2014.

[2] Pawarti. A, Nilai Pelestarian Lingkungan dalam Kearifan Lokal Lubuk Larangan Ngalau Agung di Kampuang Surau Kabupaten Dharmasraya Provinsi Sumatera Barat.Seminar Nasional Pengelolaan Sumberdaya Alam, 2012.

[3] Ngafifi. M, "Kemajuan Teknologi Dan Pola Hidup Manusia Dalam Perspektif Sosial Budaya", Jurnal Pembangunan Pendidikan: Fondasi danm Aplikasi, vol. 2, no.1, 2014.
[4] Widjaya. T A, Kearifan Lokal Masyarakat di Sekitar Kawasan Taman Nasional Lore Lindu(TNLL), Palu Sulawesi Tengah Dalam Pengelolaan Hutan dan Pemanfaatan Sumber Daya Alam, Bogor: Institut Pertanian Bogor, 2008.

[5] Siregar. L, Antropologi dan konsep kebudayaan, Jurnal antropologi papua, vol.1, no.1, Agustus 2002.

[6] Sujarwa, Manusia dan Fenomena Budaya, Yogyakarta: Pustaka Belajar, 2001.

[7] Pabbajah. M, Religiusitas dan kepercayaan masyarakat BugisMakassar, Jurnal Al-Ulum, vol.12, no.2, Desember 2012, pp. 397-418.

[8] Rahyono, Kearifan budaya dalam kata edisi revisi, Jakarta: Wedatama Widya Sastra, 2015

[9] Indrawardana. I, Kearifan lokal adat masyarakat sunda dalam hubungan dengan lingkungan alam, Jurnal komunitas, 2014.

[10] Santoso. U, Pembangunan yang berwawasan lingkungan, Jurnal lingkungan hidup, 2011.

[11] Suryadarma. I G P, Peran hutan masyarakat dalam menjaga stabilitas iklim satu kajian perspektif deep ecology (kasus masyarakat desa adat Tenganan, Bali), Jurnal konservasi flora indonesia dalam mengatasi dampak pemansan global, 2011, pp. 50-56.

[12] Adnyana. G A, Pengembangan Modul Geografi Model DEPDIKNAS Berbasis Kearifan Lokal Bali Pada Kompetensi Inti Pengetahuan Tentang Lingkungan Hidup SMA/MA Kelas XI. (Unpublished)

[13] Koentjaraningrat, Pengantar antropologi, pokok-pokok etnografi II, Jakarta: Rineka Cipta, 1989 